\title{
WHO ready to deploy Ebola vaccine in disease outbreak
}

\author{
Anne Gulland \\ London
}

For the first time during a live outbreak of Ebola, a vaccine could be used to stop the spread of the disease, the World Health Organization has said.

In a press briefing on 18 May, WHO said that it had been in discussions with the government of the Democratic Republic of Congo (DRC) about deploying the vaccine to combat the outbreak of the disease declared on 12 May.

As of 17 May there have been 20 cases of Ebola in the country, two of which have been laboratory confirmed. Three people have died in the outbreak, which is centred in the Likati area in the north of the country.

Peter Salama, WHO's executive director of emergencies, said that because the vaccine, which was shown to be safe and effective in a ring vaccination trial in Guinea in $2015,{ }^{1}$ is not yet licensed, several steps needed to be taken before it was made available to health workers, contacts of those infected, and contacts of those contacts.

He said, "We need the full acquiescence of the national regulatory authority in DRC in order to use the vaccine in an expanded access framework for compassionate use. That will also require that we have a full study protocol approved by the local ethics review board, and that we have the logistics in place to manage a ring vaccination campaign."

He said that the vaccine needed to be kept at $-80^{\circ} \mathrm{C}$, posing an "enormous challenge" in an area with poor telecommunications and road access, and without large scale electrification.

The vaccine could be deployed from Guinea in a matter of days but the regulatory and ethical approvals could take longer,

Salama said.

The DRC has not yet made a formal request for the vaccine but it has been in discussions with WHO and other partners,

Matshidiso Rebecca Moeti, WHO's regional director for Africa, said.
"We are optimistic they will work with us to consider this," she told the press briefing.

Salama said that the immediate priorities were to follow up around 400 contacts of the cases already recorded, to ensure that health workers and carers were protected with personal protective equipment, to build and deploy a mobile laboratory, and to repair airstrips and telecommunications. The charity Médecins Sans Frontières, which took a leading role during the 2014 Ebola outbreak in west Africa, has sent 10 tons of materials, four vehicles, and 20 members of staff to the affected area. It is hoping to set up two Ebola treatment centres but has been hampered by the area's poor accessibility. WHO estimates that the response will cost $\$ 10 \mathrm{~m}(£ 7.68 \mathrm{~m}$; $€ 9 \mathrm{~m})$ over the first six months.

This is the eighth time there has been an outbreak of the disease in DRC. The first ever cases of Ebola were recorded in the country-then called Zaire-in 1976.

Moeti praised the DRC government for declaring an outbreak within three weeks of the first patient arriving at hospital. She said that she was confident it would be a "short lived" event.

"We are very optimistic-DRC has extensive experience in tackling an Ebola outbreak. While the very difficult situation in west Africa was taking place, Congo managed to quietly get on with controlling an outbreak in one of their own provinces," she said.

1 Henao-Restrepo AM, Camacho A, Longini IM. Efficacy and effectiveness of an rVSV-vectored vaccine in preventing Ebola virus disease: final results from the Guinea ring vaccination, open-label, cluster-randomised trial (Ebola Ca Suffit!). Lancet 2017;389:505-18. doi:10.1016/S0140-6736(16)32621-628017403

Published by the BMJ Publishing Group Limited. For permission to use (where not already granted under a licence) please go to http://group.bmj.com/group/rights-licensing/ permissions 